\title{
Stability of viral hemorrhagic septicemia virus (VHSV) in freshwater and seawater at various temperatures
}

\author{
Laura M. Hawley, Kyle A. Garver* \\ Fisheries \& Oceans Canada, Pacific Biological Station, 3190 Hammond Bay Road, Nanaimo, British Columbia V9T 6N7, \\ Canada
}

\begin{abstract}
Three North American and 1 European viral hemorrhagic septicemia virus (VHSV) isolates taken from either a marine, freshwater, or estuarine host were assessed for survivability in raw and filtered freshwater and seawater at temperatures ranging from 4 to $30^{\circ} \mathrm{C}$. All 4 isolates were substantially more stable in freshwater than in seawater, and higher survival was observed at lower water temperatures. The average time required for $99.9 \%$ inactivation of VHSV in raw freshwater at $15^{\circ} \mathrm{C}$ was $13 \mathrm{~d}$, while in raw seawater VHSV was inactivated within an average of $4 \mathrm{~d}$. No consistent correlation was observed between the origin and the stability of the virus isolates. Freshwater isolates were not always the most stable in freshwater; similarly, seawater isolates were not consistently more stable in seawater. Virus survival was greatly enhanced in filtered freshwater with some virus strains remaining infective after $1 \mathrm{yr}$ at $4^{\circ} \mathrm{C}$.
\end{abstract}

KEY WORDS: Viral hemorrhagic septicemia virus - Virus inactivation - Great Lakes VHSV • Genotype IVb · Virus survival · Environmental factors/effects

Resale or republication not permitted without written consent of the publisher

\section{INTRODUCTION}

Viral hemorrhagic septicemia virus (VHSV) is an aquatic pathogen that infects both freshwater and marine fish species in many regions of the Northern Hemisphere. The virus belongs to the Rhabdoviridae family, genus Novirhabdovirus (Walker et al. 2005), and is the causative agent of viral hemorrhagic septicemia (VHS) disease. Due to the potential of VHSV to cause significant losses in a broad range of hosts and its ability to spread rapidly, VHS disease is one of 7 viral fish diseases listed as notifiable in the 2008 Aquatic Animal Health Code of the World Organisation for Animal Health (OIE 2008).

VHSV was first isolated in 1963 from freshwater cultured rainbow trout Oncorhynchus mykiss in Egtved, Denmark (Jensen 1963). Over the next 2.5 decades, the virus remained predominantly a pathogen of European cultured rainbow trout with only a few isolations made from several different freshwater species and, curiously, from a few marine species (Wolf 1988). VHSV was not found outside Europe until 1988, when it was isolated for the first time in North America from returning chinook $O$. tshawytscha and coho $O$. kisutch salmon at 2 separate hatcheries in Washington (Brunson et al. 1989, Hopper 1989). In addition to expanding the known geographic range, VHSV was isolated from an ever increasing number of marine species in the North Pacific and North Atlantic oceans (Meyers et al. 1992,1994,1999, Kent et al. 1998, Smail 2000, Isshik et al. 2001, Dopaz et al. 2002, Hedrick et al. 2003, Kim et al. 2003). It is unclear whether these new detections truly represent an expansion of the pathogen or are merely a consequence of increased sampling. Nonetheless, these marine detections of VHSV led to the speculation that the source for VHSV in the European rainbow trout aquaculture industry originated from a marine source which had been spread via the feeding of infected marine fish products to the cultured trout 
(Meyers \& Winton 1995, Stone et al. 1997, Dixon 1999, Einer-Jensen et al. 2004, Snow et al. 2004).

Historically, VHSV in North America had only been recovered from marine, estuarine and anadromous fish populations occurring in coastal waters of the Pacific Ocean from Alaska to California and the Atlantic Ocean waters of Maine, New Brunswick and Nova Scotia (Meyers \& Winton 1995, Olivier 2002, Hedrick et al. 2003). However, in the spring of 2005, VHSV was isolated for the first time from a mass mortality event in a freshwater environment in North America. The virus was isolated from dead or dying freshwater drum Aplodinotus grunniens in Lake Ontario (Lumsden et al. 2007). Following this initial discovery, an archived viral isolate obtained from diseased muskellunge Esox masquinongy in Lake St. Clair in 2003 was identified as VHSV, indicating the earliest detection of the virus in the Great Lakes (Elsayed et al. 2006). The virus has also been associated with large mortalities of round gobies Neogobius melanostomus in Lake Ontario and the Saint Lawrence River (Groocock et al. 2007). To date, this freshwater strain of VHSV has been isolated from 28 species of fish in the Great Lakes regions of Canada and the USA including Lake Michigan, Lake Huron, Lake St. Clair, Lake Erie, Lake Ontario, the Saint Lawrence River and from inland lakes in New York, Michigan, Wisconsin and Ohio (USDA \& APHIS 2007).

Phylogenetic analyses based on nucleotide sequence of nucleo- and glycoprotein genes illustrated that VHSV isolates group into 4 major genotypes that generally correlate with geographic location (Benmansour et al. 1997, Einer-Jensen et al. 2004, 2005 Snow et al. 2004). Genotype I encompasses European freshwater and north European marine isolates; Genotype II represents marine isolates originating from the Baltic Sea; Genotype III consists of North Sea isolates; and Genotype IV represents all North American isolates (Skall et al. 2005). Sequence analysis of the new North American freshwater isolates assigned them to a new sublineage of Genotype IV denoted as Genotype IVb
(Elsayed et al. 2006). This genotype also includes isolates from the brackish waters surrounding New Brunswick and Nova Scotia, supporting our hypothesis that the North American freshwater isolates detected in the Great Lakes may have originated among marine or estuarine fishes of the Atlantic seaboard of North America. This new Genotype IVb isolate found in the Great Lakes region is the only one outside of Europe that has been associated with significant mortality in freshwater species.

In order to perform risk assessments and make epidemiological inferences with the application to provide management and control strategies for this invasive pathogen, it is necessary to understand the factors that affect its stability in the natural environment.

The stability of VHSV in seawater and/or saltwater has been studied previously (Winton et al. 1991, Parry \& Dixon 1997, Kocan et al. 2001). However, limited information is available concerning the stability of VHSV in freshwater. Studies investigating the viability of VHSV in freshwater were restricted to short time periods (Winton et al. 1991) or a single isolate (Mori et al. 2002). Moreover, no data are available regarding the stability of Genotype IVb isolates from the Great Lakes regions when held under various environmental conditions. Therefore, in the present study a thorough comparison was conducted to evaluate the stability of 4 geographically distinct VHSV isolates in both freshwater and seawater at temperatures ranging from 4 to $30^{\circ} \mathrm{C}$.

\section{MATERIALS AND METHODS}

Virus isolates, propagation, and quantification. The 4 virus isolates compared were chosen based on their differences in geographic location, host species, water source and genogroup as summarized in Table 1. Three VHSV isolates comprise geographically distinct regions and water sources within Canada and one isolate originated from a freshwater source in Europe.

Table 1. Summary of VHS viral isolates used

\begin{tabular}{|llcclll}
\hline Isolate & Host species & Water source & Genogroup & \multicolumn{2}{c|}{ Location } & Source \\
\hline $99-001$ & $\begin{array}{l}\text { Sardine } \\
\text { Sardinops sagax }\end{array}$ & Marine & IVa & $\begin{array}{l}\text { Beaver Cove, British Columbia, Hedrick et al. (2003) } \\
\text { Canada }\end{array}$ \\
U13653 & $\begin{array}{l}\text { Drum } \\
\text { Aplodinotus grunniens }\end{array}$ & Freshwater & IVb & $\begin{array}{l}\text { Bay of Quinte, Lake Ontario, } \\
\text { Canada }\end{array}$ & Lumsden et al. (2007) \\
CA-NB00-01 & $\begin{array}{l}\text { Mummichog } \\
\text { Fundulus heteroclitus } \\
\text { Rainbow trout } \\
\text { Oncorhynchus mykiss }\end{array}$ & Brackish & IVb & $\begin{array}{l}\text { Ruisseau George Collete, } \\
\text { New Brunswick, Canada }\end{array}$ & Gagne et al. (2007) \\
F1 & & I & Egtved, Denmark & Jensen (1965) \\
\hline
\end{tabular}


Each VHS isolate was propagated on a confluent monolayer of Epithelioma papulosum cyprini (EPC) cell line (Fijan et al. 1983). Cells were grown in a T175 $\mathrm{cm}^{2}$ tissue culture flask (Nunc) containing $70 \mathrm{ml}$ minimum essential medium (MEM) (Gibco) supplemented with $10 \%$ fetal bovine serum (FBS), $1 \%$ GlutaMAX-1 and $0.06 \%$ sodium bicarbonate (Gibco) (MEM-10). Media was decanted and $200 \mu \mathrm{l}$ of cell culture supernatant from cultures exhibiting cytopathic effect (CPE) was inoculated onto cells in the flask containing residual media. After virus inoculation, cells were incubated for $1 \mathrm{~h}$ at $15^{\circ} \mathrm{C}$ followed by the addition of $70 \mathrm{ml}$ of MEM supplemented with $2 \%$ FBS, 2\% Newborn Calf Serum, 14 mM HEPES, GlutaMAX-1, $0.03 \%$ sodium bicarbonate, $20 \mu \mathrm{g} \mathrm{ml} \mathrm{m}^{-1}$ Gentamicin and $1 \times$ Antibiotic-Antimycotic (Gibco) (MEM-4). Cells remained at $15^{\circ} \mathrm{C}$ until complete destruction of the monolayer was observed. Virus infected cell cultures were centrifuged at $3100 \times g$ for $11 \mathrm{~min}$ and supernatants containing VHSV were aliquoted and stored at $-80^{\circ} \mathrm{C}$. All virus isolates were passed 2 to 5 times in cell culture before being utilized. Virus stocks were quantified using plaque assay as described previously (Burke \& Mulcahy 1980). Briefly, 8-well tissue culture plates, 70 to $100 \%$ confluent with EPC cells, were inoculated in duplicate with $100 \mu \mathrm{l}$ of a 10-fold VHSV dilution series. Plates were incubated at $15^{\circ} \mathrm{C}$ for $1 \mathrm{~h}$ to allow virus absorption, overlayed with $3 \mathrm{ml}$ per well MEM-4 supplemented with $8.8 \%$ methyl cellulose (SIGMA) and returned to $15^{\circ} \mathrm{C}$ until $\mathrm{CPE}$ was observed (5 to $7 \mathrm{~d}$ ). Cells were fixed and stained with a solution of $0.1 \%$ crystal violet and $10 \%$ formalin. Titers were recorded as plaque forming units per $\mathrm{ml}\left(\mathrm{pfu} \mathrm{ml}^{-1}\right)$.

Water parameters. The stability of the VHSV isolates was determined in fresh and seawater at 4,10, 15 and $20^{\circ} \mathrm{C}$. Stability in freshwater was further investigated at 25 and $30^{\circ} \mathrm{C}$. Both freshwater and seawater samples were collected from the wet laboratory at the Pacific Biological Station. The freshwater source was Nanaimo municipal water, dechlorinated with sand and charcoal filters and is hereafter denoted as the 'raw' freshwater sample. The seawater source was taken from the Strait of Georgia at a depth of $80 \mathrm{ft}$ (ca. $24 \mathrm{~m}$ ) and passed through sand filters; it is hereafter denoted as the ' $\mathrm{raw}^{\prime}$ ' seawater sample. Aliquots of these raw freshwater and seawater samples were subsequently passed through a $0.45 \mu \mathrm{m}$ nitrocellulose membrane filter (Millipore) to represent the 'filtered' sample. The hardness of all water sources was determined using Lamotte's direct reading titrator for total calcium and magnesium hardness. Salinity was determined using a VistaVision refractometer (VWR) and the $\mathrm{pH}$ of each water source was measured with a Beckman $\Phi 100$ ISFET pH meter.
Viral stability assay. Each of the 4 VHSV isolates was normalized to $5.3 \times 10^{7} \mathrm{pfu} \mathrm{ml}^{-1}$ with MEM-4. One $\mathrm{ml}\left(5.3 \times 10^{7} \mathrm{pfu}\right)$ of virus suspension was added to $49 \mathrm{ml}$ of each of the 4 different water conditions and incubated in the dark at 4, 10, 15 and $20^{\circ} \mathrm{C}$. In addition, raw and filtered freshwater sources were incubated at 25 and $30^{\circ} \mathrm{C}$. All water samples were stabilized to their respective temperatures for a minimum of $3 \mathrm{~d}$ prior to virus inoculation. Viable virus was titered in each water/virus combination using plaque assay at Day 0 (45 min after virus inoculation), 1, 2, 3, 7, 14, 17, 21 and every week thereafter. Virus titrations were carried out in duplicate using a serial 10 -fold dilution series to ensure countable plaque numbers. When CPE was observed, plates were stained and plaques counted. Virus titers were determined based on average plaque counts from duplicate wells. The stability of European F1 strain was evaluated 9 mo after the North American isolates. At this time, the stability of the North American isolates in raw freshwater at $4,10,15$ and $20^{\circ} \mathrm{C}$ was repeated. The $99.9 \%$ inactivation $\left(I_{99.9} ; 3-\log\right.$ reduction) was calculated by extrapolating from the log pfu $\mathrm{ml}^{-1}$ vs. days inactivation plots. The 2 time points that flank the point at which a 3 -log reduction of Day 0 'titer' was observed were used to determine the slope from which $I_{99.9}$ was extrapolated. Stabilities of the VHSV strains are reported as $I_{99.9}$.

\section{RESULTS}

\section{Water parameters}

The salinity, water hardness (as $\mathrm{CaCO}_{3}$ ) and $\mathrm{pH}$ of each water sample was measured. The freshwater samples, both raw and filtered, had a salinity of 0 ppt and the water was soft with only $11.5 \mathrm{ppm} \mathrm{CaCO}_{3}$. The $\mathrm{pH}$ of the freshwater at time zero for all assay temperatures ranged from 6.8 to 7.3. The seawater samples, both raw and filtered, had a salinity of $31 \mathrm{ppt}$ and water hardness of $5095.5 \mathrm{ppm} \mathrm{CaCO}_{3}$. The $\mathrm{pH}$ of the seawater samples at all assay temperatures was similar to the freshwater samples and ranged from 6.9 to 7.2.

\section{VHSV stability in freshwater}

Viability of 4 VHSV isolates from geographically distinct areas was determined in raw and filtered freshwater samples held at 6 different temperatures. The time, in days, required for the $I_{99.9}$ of the original (Day 0) VHSV titer in freshwater samples is shown in Fig. 1a,b. VHSV isolates were less stable in raw freshwater than in filtered freshwater, and survivability decreased with increasing temperature. 

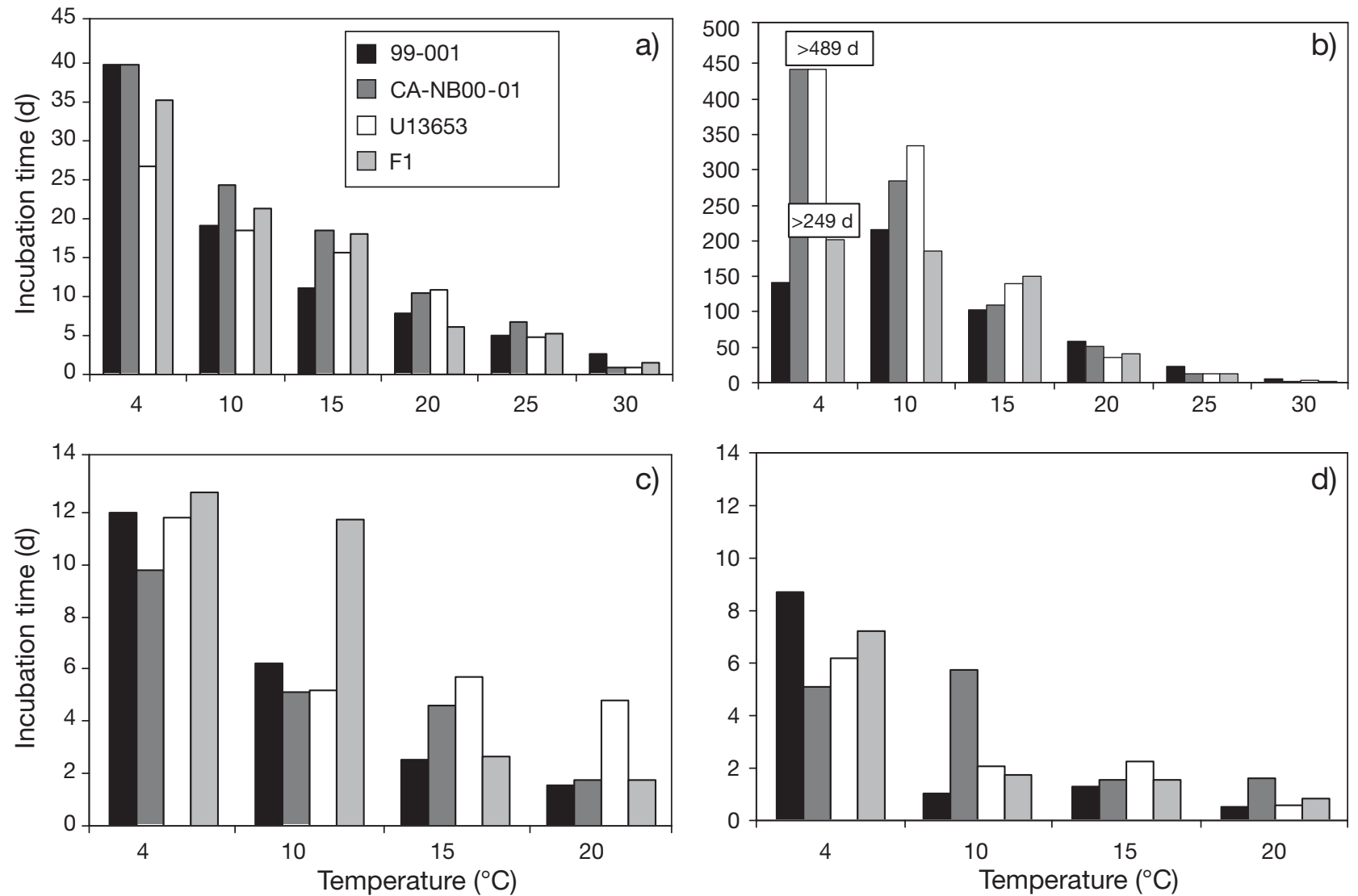

Fig. 1. Time to $99.9 \%$ inactivation of 4 geographically distinct viral hemorrhagic septicemia virus (VHSV) isolates in (a) raw freshwater, (b) filtered freshwater, (c) raw seawater and (d) filtered seawater at temperatures ranging from 4 to $30^{\circ} \mathrm{C}$. (b) The $240 \mathrm{~d}$ gap between North American and European strains in filtered freshwater at $4^{\circ} \mathrm{C}$ is due to staggered assay start dates. Note $y$-axis scales of raw and filtered freshwater are different

\section{Raw freshwater}

In the raw freshwater samples, the $4 \mathrm{VHSV}$ isolates showed similar stabilities with inactivation times $\left(I_{99.9}\right)$ ranging from $40 \mathrm{~d}$ at $4{ }^{\circ} \mathrm{C}$ to less than $1 \mathrm{~d}$ at $30^{\circ} \mathrm{C}$ (Fig. 1a). There were no large differences or patterns in the survivability observed between the 4 isolates in raw freshwater. The average time required for a 3-log reduction in VHSV infectivity at $4,10,15,20,25$ and $30^{\circ} \mathrm{C}$ was $35,21,16,9,5$, and 2 d respectively. Over the temperature range of 4 to $30^{\circ} \mathrm{C}$, virus stability decreased an average of 2 -fold with every $5^{\circ}$ incremental increase.

Repeat evaluation of the stability of each of the 3 North American isolates in raw freshwater at 4, 10, 15 and $20^{\circ} \mathrm{C}$ revealed inactivation times that ranged from $60 \mathrm{~d}$ at $4^{\circ} \mathrm{C}$ to $9 \mathrm{~d}$ at $20^{\circ} \mathrm{C}$ (Fig. 2). As noted in the first assay, stability decreased with increasing temperature, and at $4,10,15$ and $20^{\circ} \mathrm{C}$ the average $I_{99.9}$ time for the 3 North American isolates was 51, 21, 11 and $10 \mathrm{~d}$ respectively.

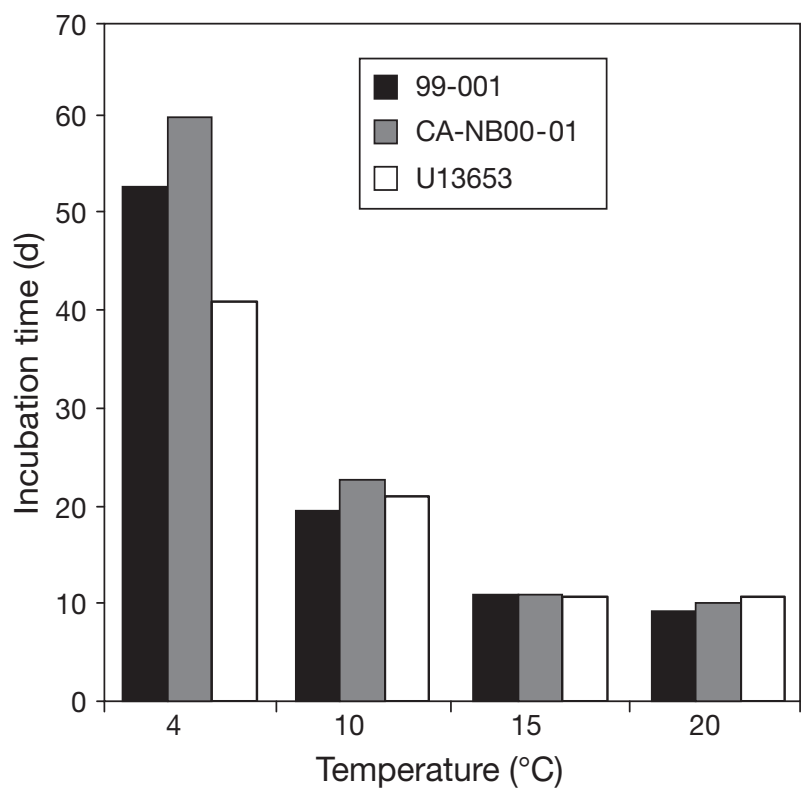

Fig. 2. Stability of North American viral hemorrhagic septicemia virus (VHSV) isolates in raw freshwater at temperatures ranging from 4 to $20^{\circ} \mathrm{C}$ (second assay). 


\section{Filtered freshwater}

The stability of each of the 4 VHSV isolates in filtered freshwater was 2 to 18 times greater than observed in the raw sample. $I_{99.9}$ times of the isolates in filtered freshwater samples ranged from $>489 \mathrm{~d}$ at $4^{\circ} \mathrm{C}$ to $<2 \mathrm{~d}$ at $30^{\circ} \mathrm{C}$ (Fig. 1b). As in the raw freshwater samples, no consistent patterns of stability were observed between the 4 isolates in filtered freshwater. In filtered freshwater, the average time required for a 3-log reduction in VHSV infectivity at 10, 15, 20, 25 and $30^{\circ} \mathrm{C}$ was $255,125,52,15$ and $3 \mathrm{~d}$, respectively. At $4^{\circ} \mathrm{C}$, filtered freshwater was a notably stabilizing medium for the virus. The Great Lakes freshwater isolate (U13653), the East Coast estuarine isolate (CA-NB0001) and the European freshwater isolate (F1) remained viable for the duration of the study resulting in $I_{99.9}$ times that exceed $489 \mathrm{~d}$ for isolates U13653 \& CANB00-01 and $249 \mathrm{~d}$ for isolate F1 (Fig. 1b).

\section{VHSV stability in seawater}

The 4 VHSV isolates were considerably less stable in seawater than freshwater. Among the seawater samples, the VHSV isolates were slightly more stable in raw seawater than in the filtered seawater samples. $I_{99.9}$ times for each of the $4 \mathrm{VHSV}$ isolates incubated in the seawater samples are shown in Fig. 1c,d.

\section{Raw seawater}

In raw seawater, viral $I_{99.9}$ times ranged from as long as $13 \mathrm{~d}$ at $4^{\circ} \mathrm{C}$ to as short as $1.5 \mathrm{~d}$ at $20^{\circ} \mathrm{C}$ (Fig. 1c). No discernable stability patterns were observed between the isolates. In raw seawater the average time required for a 3-log reduction in VHSV infectivity at 4, 10, 15 and $20^{\circ} \mathrm{C}$ was $12,7,4$ and $2 \mathrm{~d}$, respectively.

\section{Filtered seawater}

When the viral isolates were incubated in filtered seawater (Fig. 1d), $I_{99.9}$ times ranged from $8.7 \mathrm{~d}$ at $4^{\circ} \mathrm{C}$ to 0.5 $\mathrm{d}$ at $20^{\circ} \mathrm{C}$. As observed in the other water treatments tested, no consistent stability pattern was observed among the 4 isolates when held in filtered seawater. In filtered seawater, the average time required for a 3-log reduction in VHSV infectivity at $4,10,15$ and $20^{\circ} \mathrm{C}$ was $7,3,2$ and $1 \mathrm{~d}$, respectively.

\section{DISCUSSION}

The present study investigated the stability of 4 genetically and geographically distinct VHSV isolates in fresh- and seawater at different temperatures.
Notably, all the isolates were more stable in freshwater than seawater. Perhaps less surprising, all isolates were more stable at lower incubation temperatures irrespective of water type.

The objective of the present study was to determine if isolate origin and/or genetic type affects viral stability. In particular, we were interested in determining if the recent North American freshwater VHSV discovered in the Great Lakes region is more stable in freshwater than the North American marine strains, thereby providing a possible explanation for its remarkable success in the freshwater environment. Similarly, we wanted to know if VHSV isolates from the marine environment were more stable than freshwater isolates in seawater. Interestingly, results indicate that there was no correlation between isolate source (i.e. freshwater or seawater) and stability in the 'native' water type. For instance, freshwater isolates exhibited stability times similar to the marine and brackish isolates when incubated in freshwater. Likewise, marine isolates showed no greater stability over the freshwater isolates when incubated in seawater. These findings correlate with those of Parry \& Dixon (1997), who investigated the stabilities of 9 VHSV isolates in seawater and found no evidence that seawater isolates were more stable in seawater.

It is interesting to note that all VHSV isolates tested in the present study displayed longer survivability in freshwater than in seawater. This result corresponds with the report by Mori et al. (2002), who found that the infectivity of a VHSV isolate (Obama25) was more quickly lost in untreated seawater than in freshwater. It also correlates with stability studies conducted on a similar aquatic rhabdovirus, infectious hematopoietic necrosis virus (IHNV), which revealed that salinity is detrimental to IHNV survival (McAllister \& Pilcher 1974, Pietsch et al. 1977, Barja et al. 1983). Taken together, these data suggest that fish rhabdoviruses are more stable in freshwater than seawater. Hence, a freshwater environment does not pose a limitation to the introduction of VHSV from a marine environment; rather, water temperature and presence of susceptible species are the more important considerations. In the present study, it is unclear as to why VHSV isolates were more stable in freshwater. However, this may in part be due to differences in hardness of the 2 water sources. Pietsch et al. (1977) noted that IHNV survival decreased with increased water hardness. The seawater used in the present study had a water hardness of 5095.5 ppm $\mathrm{CaCO}_{3}$, whereas freshwater hardness was considerably lower, with a measurement of only 11.5 ppm $\mathrm{CaCO}_{3}$. It is possible that VHS viruses aggregated more readily in the hard seawater than in the soft freshwater, and that this aggregation may be in part responsible for reduced titers. It has been reported 
that some viruses, particularly rhabdoviruses, aggregate with increasing cationic (such as $\mathrm{Mg}^{++}, \mathrm{Ca}^{++}$) concentrations (Wallis \& Melnick 1962).

It is well documented that viral survival times are dependent on the water source in which the testing is performed, particularly if a component present in the water reduces the stability of the virus (Wedemeyer et al. 1978, Toranzo \& Hetrick 1982, Barja et al. 1983, Kamei et al. 1987a, Mori et al. 2002). Previous studies that assessed virus survival in natural water sources have indicated that viral degradation is often a result of proteolytic enzymes produced by bacteria inherent in these environments (Kamei et al. 1987b, 1988a,b,c). Additionally, it has been observed that virus inactivation is accelerated in river water or water that has passed through a fish farm (LaPatra et al. 2001) or contains sediments (Kamei et al. 1987a). Therefore, for risk analysis purposes it is necessary to determine the potential minimum and maximum virus stability times such that the data have general applicability and capture survival times that could occur in diverse natural systems. To this end, we evaluated viral stability in $0.45 \mu \mathrm{m}$ filtered water, representing a water source devoid of antiviral components, potentially maximizing viral stability, as well as a raw water sample that had undergone sand filtration, representing a source that likely contained more antiviral agents and thereby reduced viral stability. In a completely untreated water sample, decay rates might be expected to be even greater; however, due to the highly variable nature of such water sources, one was not assessed in the present study. It is also noteworthy that viral stability times obtained under controlled conditions as presented in the present study (i.e. water samples containing serum incubated in the dark at constant temperatures) are presumably longer than would be exhibited in nature when the virus would be subjected to UV light and rapidly fluctuating temperatures.

Interestingly, survival times among the raw and filtered seawater samples were fairly similar, suggesting that the virus inactivating component(s) in seawater was possibly due to a soluble factor rather than a filterable agent. Conversely, survival times of VHSV isolates when incubated in raw freshwater were considerably shorter than those observed in filtered freshwater, indicating that the component(s) having an effect on virus survivability was removed through filtration.

Results from the present study reveal that VHSV can survive for extended periods of time in both seawater and freshwater, particularly at low temperatures. VHSV in seawater at $10^{\circ} \mathrm{C}$ is stable for up to $7 \mathrm{~d}$ on average. Therefore, for waterborne transmission to occur in seawater, it needs to happen within this time period. In the marine waters of the Pacific Northwest (the seawater utilized in the present study) VHSV is endemic in Pacific herring (Hedrick et al. 2003). These fish travel in dense schools in which healthy fish are readily exposed to virus shed from infected fish. In vivo virus challenge experiments exposing Pacific herring to VHSV demonstrate that the virus is transmitted after only $1 \mathrm{~h}$ of waterborne exposure (Kocan et al. 1997, Hershberger et al. 2007). This observation, in conjunction with our current data of a stability of approximately $1 \mathrm{wk}$, could explain how VHSV is so readily spread through waterborne transmission. We showed that viral stability times in freshwater were even longer than in seawater, with VHSV surviving just over $20 \mathrm{~d}$ in raw freshwater at $10^{\circ} \mathrm{C}$, further suggesting that virus transmission can occur over long distances.

Overall, the data from the present study confirm that VHSV is stable outside of a host and suggests the need to practice biosecurity measures to prevent the spread of VHSV through aquatic environments. Disinfectants that may be used to inactivate VHSV include formalin, sodium hydroxide, chlorine and iodine compounds which have contact times ranging from 5 to $20 \mathrm{~min}$ (Wolf 1988, Smail 1999). VHSV, although stable in aquatic environments, has also been shown to be quickly inactivated using UV irradiation (Wedemeyer et al. 1978, Wedemeyer 1996, Oye \& Rimstad 2001, Yoshimizu et al. 2005). When possible, movement of infected water to another location should be avoided or measures should be taken to disinfect the viruscontaminated water.

Acknowledgements. We thank C. Yason (Atlantic Veterinary College), J. Lumsden (University of Guelph), B. Souter (Fisheries \& Oceans Canada) and J. Winton (Western Fisheries Research Center) for providing virus isolates. Thanks to J. Richard and S. Edes for their technical assistance and G. Traxler for critical review of the manuscript.

\section{LITERATURE CITED}

Barja JL, Toranzo AE, Lemos ML, Hetrick FM (1983) Influence of water temperature and salinity on the survival of IPN and IHN viruses. Bull Eur Assoc Fish Pathol 3:47-50

Benmansour A, Basurco B, Monnier AF, Vende P, Winton JR, De Kinkelin P (1997) Sequence variation of the glycoprotein gene identifies three distinct lineages within field isolates of viral haemorrhagic septicaemia virus, a fish rhabdovirus. J Gen Virol 78:2837-2846

Brunson R, True K, Yancey J (1989) VHS virus isolated at Makah National Fish Hatchery. Am Fish Soc Fish Health Sect Newsl 17:3-4

Burke JA, Mulcahy D (1980) Plaquing procedure for infectious hematopoietic necrosis virus. Appl Environ Microbiol 39:872-887

Dixon PF (1999) VHSV came from teh marine environment: clues from the literature, or just red herrings? Bull Eur Assoc Fish Pathol 19:60-65

> Dopaz CP, Bandin I, Lopez-Vazquez C, Lamas J, Noya M, Barja JL (2002) Isolation of viral hemorrhagic septicemia virus from Greenland halibut Reinhardtius hippoglos- 
soides caught at the Flemish Cap. Dis Aquat Org 50: 171-179

Einer-Jensen K, Ahrens P, Forsberg R, Lorenzen N (2004) Evolution of the fish rhabdovirus viral haemorrhagic septicaemia virus. J Gen Virol 85:1167-1179

Einer-Jensen K, Ahrens P, Lorenzen N (2005) Parallel phylogenetic analyses using the $\mathrm{N}, \mathrm{G}$ or $\mathrm{Nv}$ gene from a fixed group of VHSV isolates reveal the same overall genetic typing. Dis Aquat Org 67:39-45

Elsayed E, Faisal M, Thomas M, Whelan G, Batts W, Winton J (2006) Isolation of viral haemorrhagic septicaemia virus from muskellunge, Esox masquinongy (Mitchill), in Lake St Clair, Michigan, USA reveals a new sublineage of the North American genotype. J Fish Dis 29:611-619

Fijan N, Sulimanovic D, Bearzotti M, Muzinic D and others (1983) Some properties of the Epithelioma papulosum cyprini (EPC) cell line from carp Cyprinus carpio. Ann Inst Pasteur Virol 134E:207-220

Gagne N, Mackinnon AM, Boston L, Souter B, Cook-Versloot M, Griffths S, Olivier G (2007) Isolation of viral haemorrhagic septicaemia virus from mummichog, stickleback, striped bass and brown trout in eastern Canada. J Fish Dis 30:213-223

Groocock GH, Getchell RG, Wooster GA, Britt KL and others (2007) Detection of viral hemorrhagic septicemia in round gobies in New York State (USA) waters of Lake Ontario and the St. Lawrence River. Dis Aquat Org 76:187-192

> Hedrick RP, Batts WN, Yun S, Traxler GS, Kaufman J, Winton JR (2003) Host and geographic range extensions of the North American strain of viral hemorrhagic septicemia virus. Dis Aquat Org 55:211-220

> Hershberger PK, Gregg J, Pacheco C, Winton J, Richard J, Traxler G (2007) Larval Pacific herring, Clupea pallasii (Valenciennes), are highly susceptible to viral haemorrhagic septicaemia and survivors are partially protected after their metamorphosis to juveniles. J Fish Dis 30:445-458

Hopper K (1989) The isolation of VHSV from Chinook salmon at Glenwood Springs, Orcas Island, Washington. Am Fish Soc Fish Health Sect Newsl 17:1-2

Isshik T, Nishizawa T, Kobayashi T, Nagano T, Miyazaki T (2001) An outbreak of VHSV (viral hemorrhagic septicemia virus) infection in farmed Japanese flounder Paralichthys olivaceus in Japan. Dis Aquat Org 47:87-99

Jensen MH (1963) Preparation of fish tissue cultures for virus research. Bull Off Int Epizoot 59:131-134

Jensen MH (1965) Research on the virus of Egtved disease. Ann NY Acad Sci 126:422-426

Kamei Y, Yoshimizu M, Ezura Y, Kimura T (1987a) Effects of estuarine and marine waters on the infectivities of infectious hematopoietic necrosis virus (IHNV) and infectious pancreatic necrosis virus (IPNV). Bull Fac Fish Hokkaido Univ 38:271-285

Kamei Y, Yoshimizu M, Ezura Y, Kimura T (1987b) Screening of bacteria with antiviral activity against infectious hematopoietic necrosis virus (IHNV) from estuarine and marine environments. Bull Jpn Soc Sci Fish 53:2179-2185

Kamei Y, Yoshimizu M, Ezura Y, Kimura T (1988a) Effects of environmental water on the infectivities of infectious hematopoietic necrosis virus (IHNV) and infectious pancreatic necrosis virus (IPNV). J Appl Ichthyol 4:37-47

Kamei Y, Yoshimizu M, Ezura Y, Kimura T (1988b) Identification of Pseudomonas sp. 46 NW-04 which produces antiviral agent against fish viruses. Bull Fac Fish Hokkaido Univ 39:124-132

Kamei Y, Yoshimizu M, Ezura Y, Kimura T (1988c) Screening of bacteria with antiviral activity from fresh water salmonid hatcheries. Microbiol Immunol 32:67-73
Kent ML, Traxler GS, Kieser D, Richard J and others (1998) Survey of salmonid pathogens in ocean-caught fishes in British Columbia, Canada. J Aquat Anim Health 10: 211-219

Kim SU, Lee JI, Hong MJ, Park HS, Park SI (2003) Genetic relationship of the VHSV (viral hemorrhagic septicemia virus) isolated from cultured olive flounder, Paralichthys olivaceus, in Korea. Fish Pathol 16:1-12

Kocan R, Bradley M, Elder N, Meyers T, Batts W, Winton J (1997) North American strain of viral hemorrhagic septicemia virus is highly pathogenic for laboratory-reared Pacific herring. J Aquat Anim Health 9:279-290

Kocan RM, Hershberger PK, Elder NE (2001) Survival of the North American strain of viral hemorrhagic septicemia virus (VHSV) in filtered seawater and seawater containing ovarian fluid, crude oil and serum-enriched culture medium. Dis Aquat Org 44:75-78

LaPatra SE, Troyer RM, Shewmaker W, Jones G, Kurath G (2001) Understanding aquatic animal virus survival and trafficking and its role in risk assessment. In: Rodgers CJ (ed) Proceedings of the Office International des Epizooties (OIE) international conference on risk analysis in aquatic animal health. OIE, Paris, p 251-258

Lumsden JS, Morrison B, Yason C, Russell S and others (2007) Mortality event in freshwater drum Aplodinotus grunniens from Lake Ontario, Canada, associated with viral haemorrhagic septicemia virus, type IV. Dis Aquat Org 76: 99-111

> McAllister PE, Pilcher KS (1974) Autointerference in infectious hematopoietic necrosis virus of salmonid fish. Proc Soc Exp Biol Med 145:840-844

> Meyers TR, Winton JR (1995) Viral hemorrhagic septicemia virus in North America. Annu Rev Fish Dis 5:3-24

> Meyers TR, Sullivan J, Emmeneger E, Follett JE, Short S, Batts W, Winton JR (1992) Identification of viral hemorrhagic septicemia virus isolated from Pacific cod Gadus macrocephalus in Prince William Sound, Alaska, USA. Dis Aquat Org 12:167-175

> Meyers TR, Short S, Lipson K, Batts W, Winton JR, Wilcock J, Brown E (1994) Association of viral hemorrhagic septicemia virus with epizootic hemorrhages of the skin in Pacific herring Clupea harengus pallasi from Prince William Sound and Kodiak Island, Alaska, USA. Dis Aquat Org 19:27-37

> Meyers TR, Short S, Lipson K (1999) Isolation of the North American strain of viral hemorrhagic septicemia virus (VHSV) associated with epizootic mortality in two new host species of Alaskan marine fish. Dis Aquat Org 38:81-86

Mori KI, Lida H, Nishizawa T, Arimota M, Nakajima K, Muroga K (2002) Properties of viral hemorrhagic septicemia virus (VHSV) isolated from Japanese flounder Paralichthys olivaceus. Fish Pathol 37:169-174

OIE (Office International des Epizooties) (2008) Aquatic Animal Health Code, 11th edn. OIE, Paris

Olivier G (2002) Disease interactions between wild and cultured fish: perspectives from the American Northeast (Atlantic Provinces). Bull Eur Assoc Fish Pathol 22: 103-109

> Oye AK, Rimstad E (2001) Inactivation of infectious salmon anaemia virus, viral haemorrhagic septicaemia virus and infectious pancreatic necrosis virus in water using UVC irradiation. Dis Aquat Org 48:1-5

Parry L, Dixon PF (1997) Stability of nine viral haemorrhagic septicaemia virus (VHSV) isolates in seawater. Bull Eur Assoc Fish Pathol 17:31-36

Pietsch JP, Amend DF, Miller CM (1977) Survival of infectious 
hematopoietic necrosis virus held under various environmental conditions. J Fish Res Board Can 34:1360-1364

Skall HF, Olesen NJ, Mellergaard S (2005) Viral haemorrhagic septicaemia virus in marine fish and its implications for fish farming: a review. J Fish Dis 28:509-529

Smail DA (1999) Viral haemorrhagic septicemia. In: Woo PTK, Bruno DW (eds) Fish diseases and disorders, Vol 3. Viral bacterial and fungal infections. CABI Publishing, Wallingford, p 123-148

Smail DA (2000) Isolation and identification of viral haemorrhagic septicaemia (VHS) viruses from cod Gadus morhua with the ulcus syndrome and from haddock Melanogrammus aeglefinus having skin haemorrhages in the North Sea. Dis Aquat Org 41:231-235

Snow M, Bain N, Black J, Taupin V and others (2004) Genetic population structure of marine viral haemorrhagic septicaemia virus (VHSV). Dis Aquat Org 61:11-21

Stone DM, Way K, Dixon PF (1997) Nucleotide sequence of the glycoprotein gene of viral haemorrhagic septicaemia (VHS) viruses from different geographical areas: a link between VHS in farmed fish species and viruses isolated from North Sea cod (Gadus morhua L.). J Gen Virol 78:1319-1326

Toranzo AE, Hetrick FM (1982) Comparative stability of two salmonid viruses and poliovirus in fresh, estuarine and marine waters. J Fish Dis 5:223-231

USDA (United States Department of Agriculture), APHIS (Animal and Plant Health Inspection Service) (2007) Species affected by the Viral Hemorrhagic Septicemia (VHS)

Editorial responsibility: Mark Crane, Geelong, Victoria, Australia
Federal Order. Available at: www.aphis.usda.gov/animal_ health/animal_dis_spec/aquaculture/downloads/vhs_fed_ order.pdf (accessed 12 September 2008)

Walker PJ, Benmansour A, Calisher CH, Dietzgen R and others (2005) Family Rhabdoviridae. In: Fauquet CM, Mayo MA, Maniloff J, Desselberger U, Ball LA (eds) Virus taxonomy. VIIIth Rep Int Comm Taxonomy Viruses. Elsevier/ Academic Press, London

Wallis C, Melnick JL (1962) Cationnic stabilization: a new property of intreoviruses. Virology 16:504-506

Wedemeyer GA (1996) Physiology of fish in intensive culture systems. International Thompson Publishing, New York

Wedemeyer GA, Nelson NC, Smith CA (1978) Survival of the salmonid viruses infectious hematopoietic necrosis (IHNV) and infectious pancreatic necrosis (IPNV) in ozonated, chlorinated, and untreated waters. J Fish Res Board Can 35:875-879

Winton JR, Batts WN, Deering RE, Brunson R, Hopper K, Nishizawa T, Stehr C (1991) Characteristics of the first North American isolates of viral hemorrhagic septicemia virus. Second International Symposium on Viruses of Lower Vertebrates. Oregon State University, Corvallis, OR, p 43-50

Wolf K (1988) Viral hemorrhagic septicemia virus. In: Wolf K (ed) Fish viruses and fish viral diseases. Cornell University Press, Ithaca, NY, p 217-249

Yoshimizu M, Yoshinaka T, Hatori S, Kasai H (2005) Survivability of fish pathogenic viruses in environmental water, and inactivation of fish viruses. Bull Fish Res Agen (Suppl 2):47-54

Submitted: July 8, 2008; Accepted: October 17, 2008 Proofs received from author(s): December 16, 2008 